Tomasz Sosnowski

Uniwersytet $w$ Biatymstoku

\title{
The role of faith and Church in the implementation of fatherhood in the opinion of three generations of fathers (communication from the research)
}

This text presents a fragment of a broader study of paternity in the perspective of the three generations. This is a topic that is current and important from a pedagogical point of view. New, changing family living conditions, emerging problems of raising children, raise questions about the role of the father in the changing social reality, what was its degree of involvement in family education, what sources and factors could and still could determine the extent to which faith and the Church as a community of individuals could help in this regard. It is still necessary to seek empirical research to answer questions about the role he plays and still be able to pursue his father in the family.

Key words: Church, fatherhood, generation, faith, family.

Family is a space where the most important relationships in the life of man are the relationships between people, that is, marriage and parenthood. Slightly different roles, albeit equally important, have to fulfill in this process, both mother and father. The father and his functions in an indissoluble way are connected with the family, which is the main space of realization by the man of his fatherhood. In a social sense, the stereotype image of a man is more often found, whose role is limited to providing the material conditions of the family. As a result of the social, economic and cultural transformations, the role of the father in the process of family formation becomes particularly important and therefore there is a need to involve the fathers in the 
process of overcoming various problems related to child care, the process of educating them, organizing and inspiring participation in culture. Family is the primary environment in which a child grows and develops. Nowadays, new changing living conditions of the family, problems arising from the upbringing of the child, raise a number of questions about the role of the father in the family, among others, what is its degree of involvement in the child's education process, what sources and factors determine a man's involvement in the process.

I present the issue of the role of faith and the Church in the implementation of paternity in the perspective of the three generations of the men researched. I show how these men of the three generations perceive their own role in raising a child and what the meaning of religion is. In the text I also analyze the concept of a father and fatherhood.

The word „father" is translated from English as a father, from French père, from Latin patrem, from German vater, while in Old Polish the term father was a parent ${ }^{1}$. Following the Old Polish understanding, it should be assumed that the father is the parent, ie. the person who takes care of the child, deals with his upbringing, between him and the child there is a biological connection.

An interesting and completely dissatisfied view on the terminology related to the concept of the father is adopted by French researchers Jean Delameau and Daniel Rochea ${ }^{2}$, who consider that there is no difference in this matter. According to the authors, „the father should bring up his child and give him life; these are basic obligations, but their arrangement is, of course, differentiated according to the age, different types of communities, states, or classes"3. Such a way of interpreting and understanding the concept of father illustrates its simplicity and clarity in the way of understanding certain activities related to the role of the man in the process of raising a child. In French, a father is a person who educates and recognizes a child as his offspring, and thus we deal with the biological and social fatherhood.

Bogdan Walczak writes that ,in the consciousness of the Polishspeaking people, the two components of its original meaning emerged: the generalization (and hence the importance of the ancestor, the protoplast) and the kind of creative power (and hence the meaning of

$1 \quad$ A. Kwak: Społeczny i indywidualny wymiar rodzicielstwa, (in:) A. Kwak, (ed.): Rodzicielstwo. Między domem, prawem, stużbami społecznymi, Warszawa 2008, p. 18. 
the creator, the initiator, the founder, inventor, author)'s. Analysis of the semantic development of the word father, gives the opportunity to define his image. It presents a father as „the giver of life, the caring and loving caregiver, wise and experienced, who better knows, than his child where his good is, and who in his effective pedagogic influence must often resort to harshness and punishment. The children must obey and respect him, share mutual love and take care of him in old age"5.

The term „father" also refers to the term „fatherhood". Pointing out the difference between the concepts discussed, it should be noted that the term "father" indicates a certain state, the fact of being. The term ,paternity”, in turn, includes certain activities undertaken by men, such as the process of raising a child in the family, the provision of material conditions, taking care of the child, care of education, the preparation of a child for participation in culture ${ }^{6}$. J. Witczak ${ }^{7}$ speaks of paternity as a process no less important in parenting than motherhood. „Fatherhood is no less difficult than good motherhood. To be a modern, mature father means to have the ability to seriously reorient his life (...) and to constantly watch over the fact that accompanying the growth and development of the child, do not forget about the necessity of "growing up" with him ${ }^{8}$. The concept of fatherhood is also presented as a relationship or mutual reference between different

$4 \quad$ B. Walczak: Ojciec $w$ języku polskim, (in:) S. Jabłoński (ed.): Ojciec..., Poznań 2000, p. 48.

$5 \quad$ B. Walczak: Ojciec $w$ języku polskim, (in:) S. Jabłoński (ed.): Ojciec..., Poznań 2000 , p. 51.

$6 \quad$ More: T. Sosnowski: Ojciec we wspótczesnej rodzinie. Kontekst pedagogiczny, Warszawa 2011; T. Sosnowski: Pedagogiczny model ojcostwa-konstrukt teoretyczny, „Dziecko krzywdzone. Teoria, badania, praktyka”, 2014, vol. 13, no 3; T. Sosnowski: Ojciec we wspótczesnej rodzinie. Kontekst pedagogiczny, Warszawa 2011; T. Sosnowski: Rola ojca w przygotowaniu dzieci do uczestnictwa w kulturze $w$ rodzinach miejskich (in:) Marian P. Krysiak (ed.): Rodzina bez uzależnień, Kolno 2011; T. Sosnowski: Udziat ojców $w$ opiece nad dziećmi $w$ rodzinach miejskich (in:) E. Jaszczyszyn, J. Szada-Borzyszkowska (ed.): Edukacja dziecka - mity i fakty, Białystok 2010; T. Sosnowski: Ojciec i jego rola w życiu dziecka (in:) W. Danilewicz (ed.): Wymiary wspótczesności $w$ perspektywie pedagogiki społecznej, Warszawa 2009; T. Sosnowski: Rola i znaczenie osób dorostych $w$ relacjach czasu wolnego wspótczesnych dzieci (in:) M. Halicka, J. Halicki, K. Czykier (ed.): Zagrożenia w starości i na jej przedpolu, Białystok 2010. 
people (father - child, father - mother) ${ }^{9}$. Such a view draws attention to the relativity of this notion. It is important to note that there are the relationships between a father and a child, but also the relationships that exist between a father and a mother that have initiated the life of the child. Paternity activities are in a specific social context, and paternity itself is a process, not a moment in a man's life. The proposed approach to this term clearly emphasizes the need to perceive paternity in the context of the process rather than just a brief episode in a man's life. It indicates the full commitment of the man at every moment of family life. Age of children does not matter here. At every stage of the family life process, the father has specific family functions for children and wives.

Some researchers ${ }^{10}$, by explaining the term „fatherhood," emphasize in particular the role performed by the father in the family. Pope John Paul II addressing family issues emphasizes the following functions related to the role of the father in the family:

- responsibility for conceived life,

- caring duty of the educator together with his wife,

- work, but with the reservation that this is the work that builds, creates family bonds, serves the family, cannot be taken at the expense of the family,

- man - the father is to give tesimony of the mature Christian life $\mathrm{e}^{11}$.

It is also important here to refer also to paternity in its spiritual perspective, which is presented mainly by representatives of Christian theology. The spiritual aspect shows that the conception of life makes men not only fathers in the biological sense, but also indicates the man's attitude towards being a father. Pope John Paul II writes that „parenthood is a task of a spiritual nature - not just a physical one," and „love for the spouse ... and love for children are a natural way for men to understand and realize their fatherhood." The Pope points the fatherhood of the spiritual nature that is realized in communion with God. „To cooperate with the Creator in the creation of new human beings, that is, to contribute to the transmission of the image and likeness

$9 \quad$ K.W. Meissner:Ojciec-potrzeby dziecka a wzorzec męskości, (in:) D. Kornas-Biela (ed.), Oblicza ojcostwa, Lublin 2001, p. 193.

$10 \quad$ B. Mierzwiński: Mężczyzna istota nieznana, Warszawa 1999; A. Lepa: Ojciec i jego rola w środowisku rodziny chrześcijańskiej, „Ateneum Kapłańskie” 1982, R. 74, vol. 98, no 439; M. Wolicki: Rola matki i ojca $w$ rodzinie, Warszawa 1984; M. Sokołowska: L'evolution des rapoports familaux, „Perspectives polonaises” 4/16 (1973), cf: B. Mierzwiński: Mężczyzna istota nieznana, Warszawa 1999. 
of God to which every „born of a woman” becomes"12. The father's attitude grows out of conscious, free acceptance of co-responsibility for the nearest.

I have made paternity the subject of my research in the intergenerational perspective, ie. the participation of fathers in the process of raising a child in changing living conditions and the specific conditions that define them. I researched the fathers, representatives of three generations, which in fact conducted research proved to be a relatively difficult process. The selection of the fathers I researched was deliberate. This method of selection allowed me to grasp important issues related to the research problems and the methodological assumptions. It is important to me to know a particular person by analyzing the story of human life or the course of his life, in this case the participation of fathers in parenting in an intergenerational perspective. For this purpose, the sample used for the sample selection is the age of the examined men who represented the three generations identified for the purposes of the study as follows:

1) representatives of the oldest generation of fathers - from the age of 55 ,

2) representatives of middle-aged fathers - from 40 to 55 ,

3) representatives of the youngest generation of fathers - up to 39 years ${ }^{13}$.

Getting to know about the role of the father in the intergenerational perspective, as well as the subject of my study on the role of faith and the Church in the realization of paternity by the men examined, has been made possible through qualitative research. When discussing the role of the father in the process of parenting in the intergenerational

12 John Paul II: Letter to Families, p. 29.

13 Such a method of division may raise the question of the accepted criteria of age boundaries of the examined fathers of representatives of the three generations. It is true that it is most appropriate, but it should be noted that in the literature of the subject there is no unambiguous position. The solution that was adopted for the purpose of this paper is a reference to the social sciences and the sphere of management. This allowed for the perspective of the so-called. human resources (HR). This term, according to the classical school of economics, means work (labor) as one of the means of production. The second, more common, management area refers to individual employees and to the organization that recruits, trains, motivates and releases employees (ie, personnel policy). According to the findings directly linked to the labor market, three generations of people can now be distinguished: Baby Boomers - people born between 1946 and 1964 (in my case the oldest generation of fathers), the next generation is called Generation X (people born between 1965 and 1977 - representatives of middle-aged fathers) and Generation $\mathrm{Y}$ - born after 1978 - fathers representing the youngest generation. 
perspective, the biographical context of the male father should be taken into account in order to provide a better, more complete, and deeper understanding of paternity. Therefore, it was necessary to use the qualitative orientation and to use the appropriate method, which allowed to show the interpretative processes and the subjective experiences that shaped the paternity of the examined men.

Interesting in the context of the research topic is the look on the role of men in the education of children and the importance of faith and church, which in the opinion of fathers can help in the implementation of their own fatherhood.

Fathers of the youngest generation, they believe that both parents should be involved in education. Representatives of the oldest generation emphasize primarily the role of mother. However, everyone is aware of the significance and importance of the roles that both father and mother play in the process of parenting, although it is somewhat differently understood and consequently presented.

The fathers' actions towards children, in the perspective of the three generations, are of a different nature and concern different spheres of the child's life. Another dimension of these activities can be seen in the experience of paternity at the birth of the first child and yet another when the next one occurs. This is emphasized by the representative of the middle generation.

„At my first child I learnt how to take care and upbring him. It was not easy. The other way is to deal with a small child and to grow up with another. I tried to spend as much time with children as possible. I helped with his daily care. I went out for walks, dressed up, washed, played as soon as the work allowed me. Now with the teen is completely different. I learnt that one must talk with children no matter how old they are and even if we do not want to miss something important „(OŚ1, Jozef, 42) $)^{14}$.

It is interesting to draw attention to the types and extent of paternity activities undertaken in relation to children. It is important to note that caregiving activities related to maternity protection, the organization of children's leisure activities, etc. In view of the importance of the father in raising a child, it is important to emphasize that the examined men of the oldest and slightly lesser middle class emphasize their role primarily in material protection of the family.

„First of all, security, of financial nature” (OŚ_6, Zdzislaw, 55).

14 Identification, for example: ON_1 refers to: The oldest generation father, registration number 1 in the database. Addequate: OŚ_1: Father of the middle generation; OM_1: The father of the youngest generation. The respondents' statements in the empirical part are in the original form. 
„Hm ... yes! no ... that is ... its role in this case ... ymm ... yes so indoors ... critically ... yyy .. this ... i appreciate it because .... From the perspective ... of time I think that was too much .... There was little contact with the children, and y ... material matters came into play. For eleven years ... yyy .... I was going to Germany for holidays, instead of spending time with my family ... it was ... well ... you know, chasing rats for goods, man, because I just started building a house and ... and money was needed .. well ... and I'm sorry now! In retrospect, I theology see that ... after all, after having conversations with children, they are already adults ... because they said that no, no, missing them ... they were missing their father ... and ... also my mother ... because I do not hide, And with ... wife we went ... there ... o! ,(ON_15, Adam, 56).

"As I watch the younger generation, how much time they devote to their children ... I am really sorry that I was not able to sacrifice my children ... so much attention. Love, warmth, I say to you ... (silent voice) ,(ON_15, Adam, 56).

The above statements show the grief and sadness of the elders of the oldest generation. They notice from the perspective of the past time their own mistakes in the implementation of their own fatherhood. It was only after many years that the children became adults, the conversations they had with them built up an image of their own fatherhood, which did not make them proud. They report that they did not spend enough time with their children and that they were too much involved in securing the material sphere of their families. Today, after many years, they are aware of what is important in the life of the family and the fact that they have not found contact with their own children, which they really want to own.

Fathers representing the youngest generation differently perceive their own role in raising a child. They want to be involved in the process of education in a slightly different, broader way, aware of the importance of the presence of the father in the upbringing of the child. Professional work is not an obstacle for them actively involved in the process of raising a child.

„Although it is certainly the wife at least ... since she is initially working with the child at home so she has more time to educate him or her, but that does not mean that the father's role in the upbringing is less or less important. We need to be able to reconcile, on the one hand and on the other, work with education and then it will be best, although sometimes it is difficult „(ON_4, Tomasz, 23).

„... I do not see any problem with that. I've always tried to ... I'm lucky to work in Knyszyn and around, so yyy ... I always tried or at 
the expense of vacation, or at the cost of doing something later there to be where I should be at any given moment. I do not know ... I'm the chairman of the board of parents so ... for two years ... and also I have to find time and I see that ... In the nursery I was in school I am so that ... I see that you can manage your time, to be more present in a wider life of children in school and kindergarten „(OM_1, Adam, 32).

Respondents emphasize the need to support their wives in difficult and often embarrassing educational activities and greater personal involvement in this area. Fathers note that their distance from work places a large degree of their involvement in the process of family education. In spite of the various difficulties involved, they try to actively participate in the lives of their children, often using their vacation, or the opportunity to take up hours of work absence that has been devoted to the child. It should be noted that not all employers create such opportunities for their employees. In some cases, due to such employment conditions, the father can reconcile his / her professional career with raising children, taking part in their lives, and performing various functions in the educational institutions attended by their child, such as in a kindergarten, a school involving parenthood.

Representatives of the youngest generation are fathers who have the first place in the child's education. The fathers of the middle and the oldest generation, despite the fact that they also emphasize the importance of father participation in family life, are above all emphasizing the importance of their own actions in ensuring the existence of a material family.

It is interesting to look at some of the respondents for the role of faith and church, which in their opinion can help to play a paternal role. The voices of the middle-class fathers were the dominant ones, but not only.

"If we talk about experiences, then the experience of Christianity influenced the way I am human, how my own system of values develops, how I perceive a person, including the person who is my son and my wife, so Christianity, in general, Christianity has shaped me. I try to direct the Christian system of values, so yes, the experience of Christianity". (OM_16, Karol, 27).

The man refers to his faith, which he believes is an important element of life. Christianity, in the opinion of his father, allows him daily to lead his life in accordance with a system of values that builds upon him, which sets the course of his current family.

You know what ... on the religious level it is surely ... y ... thanks to my own fatherhood ... I just started to mingle and see y ... how great 
is the love of God to us. Because I saw y ... if I'm a weak, imperfect man I'm in a state of y ... so unconditionally y ... so unconditionally just love it how much more God y ... love us when his love is perfect. In this respect, it is simply a matter of his fatherhood, with many y ... as we often hear in various parables about such matters... I understood more because I began to look not so much as from the perspective like I- my son and my dad, just I started to look from the perspective of I - a father and my son. (OŚ_14, Piotr, age 39).

„YYY .... It means in my case, did it change? I mean, first of all, it was the first joy! First of all, there was great joy (...) Firstly, there was such a joy that ... that God blessed us so much (...) (OŚ_16, Krzysztof, 40).

„Oh yes ... in pregnancy yes, it was great! I know I was very happy and I thanked the Lord for this gift ... and ... and I begged him to be healthy and ... I was very happy, I was very happy, the first days Y .... and so I imagined how it could be, how it will be. „(OŚ_15, Sławomir, $40)$.

Respondents in the perspective of faith perceived their fatherhood and child strongly emphasizing the perspective of humanistic pedagogy, describing the child as a ,gift.” As believers, they thank God for being a father and asking for the gift of healthy offspring.

Religious references are most often seen in the statements of fathers from the middle generation. We should ask why in this group? This may be related to the fact that this group of people represents a generation that strongly affirms its relationship with the Church and has actively participated in religious practices. The Church has also played a role in the political change that has taken place in our country.

In the group of fathers from the youngest generation, only the single statements of the respondents showed the importance of God in the lives of the youngest fathers.

„Well, to give him the best value, to be honest, responsible, reasonable ... to see what and how. And importantly, to know what faith was born, what does this faith mean, and why parents, I and my wife go to church ..., ,(OM_8, Damian, 20).

„Well, somehow, I'm doing it somehow, this is a big role of God is just yyy ... well, the first thing that God lets me also this time somehow manage yyyy ...." (OM_14, Mariusz , 24). 
In the case of the younger generation, the secularization process ${ }^{15}$ may be important. As researches ${ }^{16}$ show, in recent years the number of young people declaring active participation in religious practices has decreased significantly, and therefore there may be no strong references to faith and religion.

Fathers of the eldest generation treated the church and faith in God as something obvious, constituting a constant and certain element of their lives, which I think they did not have to say because they were „obvious obviousness".

\section{ROLA WIARY I KOŚCIOŁA W REALIZACJI OJCOSTWA W OPINII TRZECH POKOLEŃ OJCÓW (KOMUNIKAT Z BADAŃ)}

Tekst ten prezentuje fragment szerszych badań dotyczących ojcostwa w perspektywie trzech generacji. Jest to temat aktualny i ważny z pedagogicznego punktu widzenia. Nowe, zmieniające się warunki życia rodziny, pojawiające się problemy związane z wychowaniem dziecka, wzbudzają szereg pytań o rolę ojca w zmieniającej się rzeczywistości społecznej, min. o to jakie było i jaki jest jego stopień zaangażowania w wychowanie rodzinne, jakie źródła i czynniki mogły oraz wciąż mogą to warunkować, w jakim stopniu wiara oraz Kościół jako wspólnota osób mogły oraz mogą wspomóc w tym zakresie badanych ojców. Należy wciąż poszukiwać na drodze badań empirycznych odpowiedzi na pytania dotyczące roli, jaką pełnił oraz wciąż może realizować ojciec w rodzinie.

Słowa kluczowe: Kościół, ojcostwo, pokolenie, wiara, rodzina.

\section{Bibliography:}

1. Delumeau J., Rochea D. (ed.): Historia ojców i ojcostwa, Warszawa 1995.

2. Jabłoński S. (ed.): Ojciec..., Poznań 2000.

15 Laicisation, the process of secularization of all spheres of social life, propagated and implemented by participants of the secular movement. The purpose of secularization is: 1) to reduce the influence of religious institutions (churches) on the way of life and conduct of individuals and entire communities; (2) loosening of the bond between the clergy of different denominations and society; 3 ) dissemination of the principle of the separation of religious institutions from the state and the pursuit of its full realization. Limiting the possibility of the Church's influence on the development of law, education and upbringing; source: http://portalwiedzy.onet.pl/10955,,,laicyzacja,haslo.html (access: 08.08.2017r.).

16 Source: Raport „Religijność i przynależność narodowa w Europie ŚrodkowoWschodniej”, V 2017, Amerykańskie Centrum Badawcze Pew ; https://pl.aleteia. org/2017/07/28/religijnosc-mlodych-na-rozdrozu-czy-sprawy-mozna-zmienic/ (access: 08.08.2017r.) 
3. Kwak A., (ed.): Rodzicielstwo. Między domem, prawem, stużbami społecznymi, Warszawa 2008.

4. Lepa A.: Ojciec i jego rola $w$ środowisku rodziny chrześcijańskiej, „Ateneum Kapłańskie" 1982, R. 74, vol. 98, no. 439.

5. Meissner K. W.: Ojciec - potrzeby dziecka a wzorzec męskości, (in:) D. Kornas-Biela (ed.), Oblicza ojcostwa, Lublin 2001, p. 193.

6. Mierzwiński B. Mężczyzna istota nieznana, Warszawa 1999.

7. John Paul II: Apostolic Exhortation „Familiaris Consortio”, Poznań 1983.

8. John Paul II: Letter to Families.

9. Sosnowski T.: Ojciec we wspótczesnej rodzinie. Kontekst pedagogiczny, theology Warszawa 2011.

10. Sosnowski T.: Pedagogiczny model ojcostwa-konstrukt teoretyczny, „Dziecko krzywdzone. Teoria, badania, praktyka” 2014, vol. 13, nr 3.

11. Sosnowski T.: Rola ojca w przygotowaniu dzieci do uczestnictwa $w$ kulturze w rodzinach miejskich (in:) Marian P. Krysiak (ed.): Rodzina bez uzależnień, Kolno 2011.

12. Sosnowski T.: Udział ojców $w$ opiece nad dziećmi $w$ rodzinach miejskich (in:) E. Jaszczyszyn, J. Szada-Borzyszkowska (ed.): Edukacja dziecka mity i fakty, Białystok 2010.

13. Sosnowski T.: Ojciec i jego rola $w$ życiu dziecka (in:) W. Danilewicz (ed.): Wymiary wspótczesności $w$ perspektywie pedagogiki spotecznej, Warszawa 2009.

14. Sosnowski T.: Rola i znaczenie osób dorostych $w$ relacjach czasu wolnego wspótczesnych dzieci (in:) M. Halicka, J. Halicki, K. Czykier (ed.): Zagrożenia w starości i na jej przedpolu, Białystok 2010.

15. Witczak J.: Ojcostwo bez tajemnic, Warszawa 1987.

16. Wolicki M.: Rola matki i ojca w rodzinie, Warszawa 1984. 